\title{
Proceeding
}

Supplementary Issue: Spring Conferences of Sports Science. Costa Blanca Sports Science Events, 14-15 June 2019. Alicante, Spain.

\section{1 vs 1 in the major European football championship}

\author{
TOMMASO TROCCHIA ${ }^{1}$, , RICCARDO IZZO², FRANCESCA D'ELIA ${ }^{1}$ \\ 1 University of Salerno, Italy \\ 2University Carlo Bo of Urbino, Italy
}

\begin{abstract}
The new millennium was marked by the epic of the legendary Barcelona of Guardiola, the coach who revolutionized the world of football with his tiki taka The search for this game made of fast ball exchanges, continuous changes of position and search for free space to occupy, however, has downgraded what is one of the main technical skills of the game of football, the dribbling. Starting with football schools Pedagogical value of the body and physical activity in childhood. 1vs1 has been set aside to favour other technical fundamentals, so we are in a period where fewer and fewer players take responsibility for trying a game in 1vs1, but prefer to pass the ball to their closest partner (Giordano L. et all 2019). This second study has analysed the scorer rankings of the top 4 European championships (Serie A, Premier League, Spanish League, Bundesliga) of the 2009/2010 and 2017/2018 seasons, taking into account not only the total goals, but also the average shots per game and the average dribbling per game. Keywords: Dribbling; Soccer; Performance analysis; Video analysis.
\end{abstract}

\section{Cite this article as:}

Trocchia, T., Izzo, R., \& D'Elia, F. (2019). 1 vs 1 in the major European football championship. Journal of Human Sport and Exercise, 14(4proc), S1128-S1134. doi:https://doi.org/10.14198//hse.2019.14.Proc4.77

Corresponding author. University of Salerno, Italy.

E-mail: tommasotrocchia@hotmail.com

Supplementary Issue: Spring Conferences of Sports Science. Costa Blanca Sports Science Events, 14-15 June 2019. Alicante, Spain.

JOURNAL OF HUMAN SPORT \& EXERCISE ISSN 1988-5202

(c) Faculty of Education. University of Alicante

doi:10.14198/jhse.2019.14.Proc4.77

S1128 $|2019|$ Proc4 | VOLUME 14

C 2019 University of Alicante 


\section{INTRODUCTION}

The football is a sport, in Italy, with wide popularity (Giordano et al, 2019, Raiola et al, 2019, 2018, Raiola, D'Isanto, 2016, Trocchia et al, 2019). The rhythm play has become speedier in modern football in the last recent years and players can run faster, perform technical skills with higher speed and better make tactical decision (Altavilla et al, 2017). Soccer is an high-situational sport with an high agonistic engagement such to require the development of all the conditional capacities (Izzo et al, 2019, Gaetano \& Rago, 2014), general and specific motor skills (Tiziana et al., 2017, D'Isanto et al, 2019, D'Isanto, 2016) such as the dribbling. This second study analysed the scorer rankings of the 4 major European football championships (Serie A, Premier League, Spanish League, Bundesliga) after 8 years (2009/10 and 2017/18) and took into account the total goals, average shots per game and average dribbling per game. The aim is to see how much and how dribbling can influence the finalization of the game and thus the opportunities to achieve or build goal actions by a footballer. These two years have been chosen because, the 2009/2010 season is the first where you could have all the data reported later in this research, 2017/2018 is the last full season, at the time of the study the season 2018/19 was not yet finished (Silvestri et al, 2019).

\section{METHOD}

The study method is experimental. The scoring lists of the 4 major European football championships (Serie A, Premier League, Spanish League, Bundesliga) have been taken into consideration after 8 years (2009/10 and 2017/18). The data for calculating goals, average dribbling per game and average shots per game were extrapolated from the videos of the goals examined and from the WhoScored.com website. The statistical analysis of data foresees the use of the averages and of the Test $t$ student for estimate the performance pre and post for each group (in the years 2009/10 and 2017/18). All the data was processed using SPSS 22.0 (SPSS Inc., Chicago, IL, USA).

\section{RESULTS}

Table 1. Serie A scorers ranking (2009/2010 and 2017/2018)

\begin{tabular}{llllllll}
\hline & \multicolumn{3}{c}{ Serie A 2009/10 } & \multicolumn{5}{c}{ Serie A 2017/18 } \\
\hline $\begin{array}{l}\text { Football } \\
\text { player }\end{array}$ & $\begin{array}{l}\text { Average } \\
\text { shots } \\
\text { match }\end{array}$ & $\begin{array}{l}\text { Average } \\
\text { fribbling } \\
\text { for match }\end{array}$ & $\begin{array}{l}\text { Total } \\
\text { goals }\end{array}$ & $\begin{array}{l}\text { Football } \\
\text { player }\end{array}$ & $\begin{array}{l}\text { Average } \\
\text { shots } \\
\text { match }\end{array}$ & $\begin{array}{l}\text { Average } \\
\text { fribbling } \\
\text { for match }\end{array}$ & $\begin{array}{l}\text { Total } \\
\text { goals }\end{array}$ \\
\hline Di Natale & 4.3 & 0.7 & 29 & Icardi & 3 & 0.3 & 29 \\
Milito & 2.5 & 0.8 & 22 & Immobile & 3.3 & 0.8 & 29 \\
Pazzini & 2 & 0.1 & 19 & Dybala & 3.5 & 2.8 & 22 \\
Miccoli & 4.2 & 1 & 19 & Quagliarella & 3.2 & 0.5 & 19 \\
Gilardino & 2.4 & 0.1 & 15 & Mertens & 3.4 & 1.1 & 18 \\
Borriello & 2.8 & 0.7 & 14 & Dzeko & 4.2 & 1.1 & 16 \\
Vucinic & 2.9 & 1.8 & 14 & Higuain & 2.9 & 1.5 & 16 \\
Barreto & 1.9 & 0.4 & 14 & Simeone & 2.8 & 0.8 & 14 \\
Totti & 2.8 & 0.9 & 14 & lago Falque & 2.1 & 1.2 & 12 \\
Cavani & 2.7 & 0.9 & 13 & Inglese & 2.2 & 0.9 & 12 \\
Matri & 1.9 & 0.8 & 13 & Lasagna & 2.5 & 0.1 & 12 \\
Pato & 2.5 & 2.7 & 12 & Milinkovic & 2.6 & 1.6 & 12 \\
Maccarone & 3.3 & 1.9 & 12 & Antenucci & 2 & 0.9 & 11 \\
Di Vaio & 2.6 & 0.2 & 12 & llicic & 2.9 & 2.1 & 11 \\
\hline
\end{tabular}




\begin{tabular}{llllllll}
\hline Eto'o & 3.1 & 0.9 & 12 & Luis Alberto & 2.4 & 1.7 & 11 \\
Hamsik & 2.4 & 0.8 & 12 & Pavoletti & 2.6 & 0.1 & 11 \\
\hline
\end{tabular}

Table 2. Premier League scorers ranking (2009/2010 and 2017/2018)

\begin{tabular}{|c|c|c|c|c|c|c|c|}
\hline \multicolumn{4}{|c|}{ Premier League 2009/10 } & \multicolumn{4}{|c|}{ Premier League 2017/18 } \\
\hline $\begin{array}{l}\text { Football } \\
\text { players }\end{array}$ & $\begin{array}{l}\text { Average } \\
\text { shots for } \\
\text { match }\end{array}$ & $\begin{array}{l}\text { Average } \\
\text { dribbling } \\
\text { for match }\end{array}$ & $\begin{array}{l}\text { Total } \\
\text { goals }\end{array}$ & $\begin{array}{l}\text { Football } \\
\text { players }\end{array}$ & $\begin{array}{c}\text { Average } \\
\text { shots for } \\
\text { match }\end{array}$ & $\begin{array}{l}\text { Average } \\
\text { dribbling } \\
\text { for match }\end{array}$ & $\begin{array}{l}\text { Total } \\
\text { goal }\end{array}$ \\
\hline Drogba & 5.6 & 1.2 & 29 & Salah & 4 & 2.2 & 32 \\
\hline Rooney & 5.7 & 1.3 & 26 & Kane & 5 & 1.3 & 30 \\
\hline Bent & 3 & 0.4 & 24 & Aguero & 3.8 & 2.2 & 21 \\
\hline Tevez & 3.6 & 1.3 & 23 & Vardy & 1.9 & 0.6 & 20 \\
\hline Lampard & 3.9 & 0.4 & 22 & Sterling & 2.6 & 1.9 & 18 \\
\hline Defoe & 3.3 & 0.9 & 18 & Lukaku & 2.5 & 1 & 16 \\
\hline Torres & 3.6 & 1.4 & 18 & Firmino & 2.3 & 1.3 & 15 \\
\hline Fabregas & 3.2 & 1.9 & 15 & Lacazette & 2.1 & 1 & 14 \\
\hline Adebayor & 2.2 & 1.2 & 14 & $\begin{array}{c}\text { Gabriel } \\
\text { Jesus }\end{array}$ & 1.9 & 0.8 & 13 \\
\hline Saha & 2.9 & 0.6 & 13 & Hazard & 2.1 & 4.9 & 12 \\
\hline Agbonlhaor & 1.8 & 0.6 & 13 & Son & 2 & 1.6 & 12 \\
\hline Malouda & 1.9 & 1.4 & 13 & Mahrez & 2 & 2.3 & 12 \\
\hline Berbatov & 3 & 0.9 & 12 & Murray & 1.5 & 0.2 & 12 \\
\hline Anelka & 3 & 1 & 11 & Arnautovic & 2.3 & 1.8 & 11 \\
\hline Arsavin & 2.9 & 1.4 & 10 & Morata & 2.5 & 1 & 11 \\
\hline Carew & 2 & 0.5 & 10 & Eriksen & 2.6 & 0.8 & 10 \\
\hline
\end{tabular}

Table 3. Bundesliga scorers ranking (2009/2010 and 2017/2018)

\begin{tabular}{|c|c|c|c|c|c|c|c|}
\hline \multicolumn{4}{|c|}{ Bundesliga 2009/10 } & \multicolumn{4}{|c|}{ Bundesliga 2017/18 } \\
\hline $\begin{array}{l}\text { Football } \\
\text { players }\end{array}$ & $\begin{array}{l}\text { Average } \\
\text { shots for } \\
\text { match }\end{array}$ & $\begin{array}{l}\text { Average } \\
\text { dribbling } \\
\text { for match }\end{array}$ & $\begin{array}{l}\text { Total } \\
\text { goals }\end{array}$ & $\begin{array}{l}\text { Football } \\
\text { players }\end{array}$ & $\begin{array}{l}\text { Average } \\
\text { shots for } \\
\text { match }\end{array}$ & $\begin{array}{l}\text { Average } \\
\text { dribbling } \\
\text { for match }\end{array}$ & $\begin{array}{l}\text { Total } \\
\text { goals }\end{array}$ \\
\hline Dzeko & 4.5 & 2 & 22 & Lewandowski & 4.2 & 0.6 & 29 \\
\hline Kiesling & 3 & 1.1 & 21 & Petersen & 2 & 0.9 & 15 \\
\hline Barrios & 3 & 0.9 & 19 & Volland & 1.8 & 0.8 & 14 \\
\hline Kurany & 3.5 & 0.8 & 18 & Uth & 1.7 & 0.6 & 14 \\
\hline Robben & 3.4 & 4 & 16 & Fullfrug & 2.6 & 0.6 & 14 \\
\hline Pizarro & 2.6 & 1.2 & 16 & Kramaric & 2.4 & 0.6 & 13 \\
\hline Cacau & 2.4 & 1.1 & 13 & Gregoritsch & 2.9 & 0.4 & 13 \\
\hline Muller & 1.7 & 1.2 & 13 & Werner & 3 & 0.8 & 13 \\
\hline Bunjaku & 2.5 & 1.5 & 12 & Finnbogason & 2.3 & 0.9 & 12 \\
\hline Derdyok & 2.9 & 0.7 & 12 & Kalou & 1.6 & 1.1 & 12 \\
\hline Ibisevic & 2.6 & 0.4 & 12 & Burgstaller & 1.7 & 0.8 & 11 \\
\hline Grafite & 2.2 & 1.7 & 11 & Selke & 1.7 & 0.9 & 10 \\
\hline Olic & 2.2 & 0.6 & 11 & Gnarby & 2.2 & 2 & 10 \\
\hline Ramos & 2.1 & 1.6 & 10 & Hazard & 2.6 & 1.5 & 10 \\
\hline Meier & 2.3 & 0.5 & 10 & Didavi & 1.8 & 0.5 & 9 \\
\hline Bancè & 3.1 & 1.1 & 10 & Augustin & 1.5 & 0.9 & 9 \\
\hline
\end{tabular}


Table 4. Spanish Ligue scorers ranking (2009/2010 and 2017/2018)

\begin{tabular}{|c|c|c|c|c|c|c|c|}
\hline \multicolumn{4}{|c|}{ Spagnish Liga 2009/10 } & \multicolumn{4}{|c|}{ Spagnish Liga 2017/18 } \\
\hline $\begin{array}{l}\text { Football } \\
\text { players }\end{array}$ & $\begin{array}{l}\text { Average } \\
\text { shots for } \\
\text { match }\end{array}$ & $\begin{array}{l}\text { Average } \\
\text { dribbling } \\
\text { for match }\end{array}$ & $\begin{array}{l}\text { Total } \\
\text { goals }\end{array}$ & $\begin{array}{l}\text { Football } \\
\text { players }\end{array}$ & $\begin{array}{l}\text { Average } \\
\text { shots for } \\
\text { match }\end{array}$ & $\begin{array}{l}\text { Average } \\
\text { dribbling } \\
\text { for match }\end{array}$ & $\begin{array}{l}\text { Total } \\
\text { goals }\end{array}$ \\
\hline Messi & 4.7 & 4.1 & 34 & Messi & 5.5 & 5.1 & 34 \\
\hline Higuain & 3.1 & 1.4 & 27 & Ronaldo & 6.6 & 1.1 & 26 \\
\hline Ronaldo & 7.3 & 3.1 & 26 & Suarez & 3.7 & 1.2 & 25 \\
\hline Villa & 4.3 & 0.7 & 21 & lago Aspas & 2.8 & 1.7 & 22 \\
\hline Forlan & 3.8 & 0.5 & 18 & Stuani & 2.2 & 0.5 & 21 \\
\hline Ibrahimovic & 3.4 & 0.7 & 16 & Griezmann & 2.3 & 0.9 & 19 \\
\hline Soldado & 3.5 & 0.3 & 16 & $\begin{array}{l}\text { Maxi } \\
\text { Gomez }\end{array}$ & 2.3 & 0.4 & 17 \\
\hline $\begin{array}{l}\text { Luis } \\
\text { Fabiano }\end{array}$ & 3.3 & 0.7 & 15 & Bale & 3 & 1.2 & 16 \\
\hline Llorente & 3.1 & 0.8 & 14 & Rodrigo & 2.5 & 1.2 & 16 \\
\hline Nino & 3.4 & 0.4 & 14 & Gerard & 2.8 & 1.7 & 16 \\
\hline Aguero & 2.8 & 2.2 & 12 & Bacca & 2.1 & 1 & 15 \\
\hline Pedro & 1.1 & 0.7 & 12 & $\begin{array}{l}\text { William } \\
\text { Josè }\end{array}$ & 2.6 & 0.5 & 15 \\
\hline Kanoute & 1.8 & 0.4 & 12 & Angel & 2.1 & 0.7 & 13 \\
\hline Arduiz & 2.4 & 0.6 & 12 & Zaza & 2.2 & 0.4 & 13 \\
\hline Bermejo & 2 & 0.4 & 12 & Oyarzabal & 1.9 & 1.1 & 12 \\
\hline Negredo & 2.2 & 0.5 & 11 & Santi Mina & 1.3 & 0.6 & 12 \\
\hline
\end{tabular}

Table 5. Comparative average of the four championships examined in the year 2009/10

\begin{tabular}{lccc}
\hline $\mathbf{2 0 0 9 / 2 0 1 0}$ & Average shots for match & Average dribbling for match & Average goal \\
\hline Serie A & 2.77 & 0.92 & 15.38 \\
Premier League & 3.23 & 1.03 & 16.88 \\
Liga Spagnola & 3.26 & 1.09 & 17 \\
Bundesliga & 2.75 & 1.28 & 14.13 \\
Total Media & 3 & 1.08 & 15.84 \\
\hline
\end{tabular}

Table 6. Comparative average of the four championships examined in the year 2017/2018

\begin{tabular}{lccc}
\hline $\mathbf{2 0 1 7 / 2 0 1 8}$ & Average shots for match & Average dribbling for match & Average goal \\
\hline Serie A & 2.85 & 1.09 & 15.94 \\
Premier League & 2.57 & 1.56 & 16.19 \\
Liga Spagnola & 2.87 & 1.21 & 18.25 \\
Bundesliga & 2.25 & 0.87 & 13 \\
Total Media & 2.63 & 1.18 & 15.84 \\
\hline
\end{tabular}


Table 7. T-test: Significant difference with $\mathrm{p}=0.002$

\begin{tabular}{|c|c|c|c|c|c|c|c|c|}
\hline & \multicolumn{5}{|c|}{ Coupled differences } & \multirow{3}{*}{$t$} & \multirow{3}{*}{$\mathrm{gl}$} & \multirow{3}{*}{$\begin{array}{l}\text { Sign. (with } \\
\text { two tails) }\end{array}$} \\
\hline & \multirow[t]{2}{*}{ Average } & \multirow{2}{*}{$\begin{array}{l}\text { Standard } \\
\text { deviation. }\end{array}$} & \multirow{2}{*}{$\begin{array}{c}\text { Average } \\
\text { standard error }\end{array}$} & \multicolumn{2}{|c|}{$\begin{array}{l}\text { Confidence interval of the } \\
\text { difference of } 95 \%\end{array}$} & & & \\
\hline \multirow[b]{2}{*}{$\begin{array}{l}\text { VAR01 - } \\
\text { VAR02 }\end{array}$} & & & & Lower & Higher & & & \\
\hline & .36800 & .25986 & . 08218 & 18211 & .55389 & 4.478 & 9 & .002 \\
\hline
\end{tabular}

Meaningfulness level's was been placed at $p<0.05$.

\section{DISCUSSION}

Table 7 shows a significant difference with $p=0.002$, therefore below the level of significance placed at $p>0.05$, between the teams compared over 10 years; it means that there has been a change in terms of the finalization of the game and therefore of goal occasions, in our study in negative.

Tables 5 and 6 compare the averages between the different championships analysed between 2009/10 and 2017/18. The A series has gone from an average shots per game of $2.77(2009 / 10)$ to an average of 2.85 (2017/2018), with an increase of $0.09 \%$. Average dribbling has risen from 0.92 per game to an average of $1.09(+0.17 \%)$. The average goal of the first 16 players in the $2009 / 2010$ scoring list was 15.38 , while in 2017/2018 it increased to $15.94(+0.56)$; so we can say that after 8 years, in Serie A, there was an increase in all the parameters analysed.

In the Premier League, the average number of shots per game increased from 3.23 in 2009/2010 to 2.57 in $2017 / 2018(-0.56 \%)$; the average number of dribbles per game increased from 1.03 to $1.56(+0.53)$; the average number of goals decreased from 16.88 to $16.19(-0.69)$; so there was a decrease in the average number of shots per game and goals, but an increase in the average number of dribbles per game.

In the Spanish La Liga the average number of shots per game decreased from 3.26 in 2009/2010 to 2.87 in $2017 / 2018$ (-0.39). Average dribbling per game increased from 1.09 to 1.21 over 8 years $(+0.12)$. The average number of goals, on the other hand, rose from 17 in 2009/2010 to 18.25 in 2017/2018. There was therefore a substantial increase in the average goal after 8 years $(+1.25)$, a slight increase in the average dribbling per game $(+0.12)$, while the average shot per game decreased by 0.39 .

Finally, in the Bundesliga, the average number of shots per game went from 2.75 to 2.25. Average dribbling from 1.28 to 0.87 last season, average goal 14.13 to 13 .

The Bundesliga is the one that, among the major European championships, seems to have suffered more a decline in technical fundamentals such as shooting and dribbling and also in the average goal. In fact, all the parameters have decreased: 0.50 for the average shot, 0.41 for the average dribbling and even 1.13 for the average goal.

\section{CONCLUSIONS}

The major European championships compared over a decade, on some technical variables of football such as the shots on goal achieved, the dribbling and goals scored, have shown significant changes in terms of organization and construction of the game and have had, as a negative consequence, the reduction of opportunities by goals. The results of this study show that the opportunities to score (goal) are influenced by 
the type of game and the use of fundamentals. Therefore, it is essential to continuously monitor the activity and progress of your team, analyse game trends and technical-tactical choices, in order to always have the opportunity to modify and adapt the annual schedule.

\section{REFERENCES}

Altavilla G., Riela L., Di Tore P.A., Raiola G., (2017). The physical effort required from professional football players in different playing positions. Journal of Physical Education and Sport, 17(3):20072012.

D'Isanto, T. (2016) Pedagogical value of the body and physical activity in childhood. Sport Science, 9 (Supplement 2): 13-18.

Gaetano, R., Rago, V. (2014). Preliminary study on effects of hiit-high intensity intermittent training in youth soccer players, Journal of Physical Education and Sport, 14 (2): 148-150.

Giordano, L., Federici, A., Valentini, M., D'elia, F. (2019) Dribbling in football: Confronting learning theories, Journal of Human Sport and Exercise, 14 (Proc2), pp. S228-S232. https://doi.org/10.14198/ihse.2019.14.proc2.10

Ceruso, R., Esposito, G., Federici, A., Valentini, M., D'isanto, T., Preliminary work about the basis data for monitoring youth soccer team planning training(2019) Journal of Human Sport and Exercise, 14 (Proc2), pp. S251-S257. https://doi.org/10.14198/jhse.2019.14.proc2.14

Raiola, G., D'Isanto, T., D'Elia, F., Altavilla, G. (2019). The evaluation of the improvement of the endurance in the transition period. The European Proceedings of Social \& Behavioural Sciences EpSBS, in press.

Tiziana, D., Antonetta, M., Gaetano, A. (2017). Health and physical activity, Sport Science, 10(1):100105.

D'Isanto, T., D'Elia, F., Raiola, G., Altavilla, G. (2019) Assessment of sport performance: Theoretical aspects and practical indications, Sport Mont, 17 (1), pp. 79-82.

Raiola, G., D'elia, F., Altavilla, G. (2018) Physical activity and sports sciences between European Research Council and academic disciplines in Italy, Journal of Human Sport and Exercise, 13, pp. S283-S295. https://doi.org/10.14198//hse.2018.13.proc2.13

Raiola, G., D'isanto, T. (2016) Assessment of periodization training in soccer, Journal of Human Sport and Exercise, 11 (Proc1), pp. S267-S278. https://doi.org/10.14198/jhse.2016.11.proc1.19

Gaetano, R., Rago, V. (2014) Preliminary study on effects of hiit-high intensity intermittent training in youth soccer players, Journal of Physical Education and Sport, 14 (2), pp. 148-150.

Giordano, L., Federici, A., Valentini, M., D'elia, F. (2019) Dribbling in football: Confronting learning theories, Journal of Human Sport and Exercise, 14 (Proc2), pp. S228-S232. https://doi.org/10.14198/ihse.2019.14.proc2.10

Ceruso, R., Esposito, G., Federici, A., Valentini, M., D'isanto, T., Preliminary work about the basis data for monitoring youth soccer team planning training(2019) Journal of Human Sport and Exercise, 14 (Proc2), pp. S251-S257. https://doi.org/10.14198/jhse.2019.14.proc2.14

Giordano, L., Federici, A., Valentini, M., D'elia, F. (2019) Dribbling in football: Confronting learning theories Journal of Human Sport and Exercise, 14 (Proc2), pp. S228-S232. https://doi.org/10.14198/jhse.2019.14.proc2.10

Izzo, R., Sopranzetti, S., Hosseini Varde'I, C., Molitierno, G. (2018)Video tracking for the detection of external load to establish proper parameters in elite soccer players during high intensity training, Journal of Physical Education and Sport, 18, art. no. 178, pp. 1199-1202. 


\section{(c) $(7)(\mathrm{E})$}

This work is licensed under a Attribution-NonCommercial-NoDerivatives 4.0 International (CC BY-NC-ND 4.0). 